\section{Challenges in research and management of hepatitis $E$ virus infection in Cuba, Mexico, and Uruguay}

\author{
Mauricio Realpe-Quintero, ${ }^{1}$ Maria C. \\ Montalvo, ${ }^{2}$ Santiago Mirazo, ${ }^{3}$ Arturo \\ Panduro, ${ }^{4}$ Sonia Roman, ${ }^{4}$ Reimar \\ Johne, ${ }^{5}$ and Nora A. Fierro ${ }^{6}$
}

Suggested citation Realpe-Quintero M, Montalvo MC, Mirazo S, Panduro A, Roman S, Johne R, et al. Challenges in research and management of hepatitis E virus infection in Cuba, Mexico, and Uruguay. Rev Panam Salud Publica. 2018;42:e41. https://doi. org /10.26633/RPSP.2018.41

\section{ABSTRACT}

The symposium "Epidemiology of Hepatitis E virus (HEV) Infection and Associated Immune Response" was held at the Universidad de Guadalajara, Mexico, on 14 June 2017, to define the status of research on HEV infection in three countries in Latin America and the Caribbean (LAC)-Cuba, Mexico, and Uruguay-compared to the situation in Germany. Scientists identified specific research gaps in understanding HEV transmission and the resulting impact on

Laboratorio de Desarrollo de Biologicos, Hospital Veterinario de Pequeñas Especies, Centro Universitario de Ciencias Biologicas y Agropecuarias, Universidad de Guadalajara, Guadalajara, Jalisco, Mexico.

2 Laboratorio Nacional de Referencia de Hepatitis Virales, Instituto de Medicina Tropical Pedro Kouri, Havana, Cuba.

Laboratorio de Virologia, Universidad de la Republica, Montevideo, Uruguay.

4 Servicio de Biologia Molecular, Hospital Civil de Guadalajara Fray Antonio Alcalde, Centro Universitario de Ciencias de la Salud, Universidad de Guadalajara, Guadalajara, Jalisco, Mexico.

Department of Biological Safety, German Federal Institute for Risk Assessment, Berlin, Germany.

6 Unidad de Inmunovirologia, Servicio de Biología Molecular, Hospital Civil de Guadalajara Fray Antonio Alcalde, Centro Universitario de Ciencias de la Salud, Universidad de Guadalajara, Guadalajara, Jalisco, Mexico. Send correspondence to: Nora A. Fierro, noraalma@gmail.com development of disease in the three abovementioned LAC countries. Specific recommendations for implementing standardized serologic and molecular diagnostic methods and epidemiologic, basic, and applied research aimed to develop prevention and handling strategies for this infection, along with the associated comorbidities in the three LAC countries, were also discussed. Given similar demographic, sanitary, and economic conditions in other LAC countries that could predispose them to be at high risk for HEV transmission and infection, these research gaps and recommendations might apply to the entire LAC region. This report was prepared by meeting participants based on 1) symposium presentations, 2) literature reviews, and 3) group discussions.

Keywords Hepatitis E virus; Cuba; Mexico; Uruguay; Latin America; Caribbean region.

The World Health Organization (WHO) estimates that 20 million hepatitis E virus (HEV) infections occur worldwide each year (1). HEV infection is endemic to many low-income countries and is recognized as an emerging infection in developed regions (e.g., Europe). HEV usually causes self-limiting hepatitis but occasionally leads to fulminant liver failure and, in immunosuppressed patients, chronic HEV infection. Furthermore, the frequent detection of HEV-specific antibodies in the sera of people with no history of hepatitis indicates that mild and subclinical courses of $\mathrm{HEV}$ infection are also common (2). The virus is mainly transmitted via the fecal-oral route, and waterborne epidemics due to fecally contaminated drinking water are typical for hepatitis $\mathrm{E}$ in developing countries, including those in Latin America and the Caribbean (LAC) (3-4). In addition, the zoonotic potential of HEV is recognized, with pigs being the main animal reservoir for two of the human-pathogenic HEV genotypes. Meat prepared from infected animals or other food contaminated with virus-containing excretions may therefore represent sources of HEV infection (5). An HEV vaccine was licensed in China in 2011 but is not available worldwide.

$\mathrm{HEV}$ includes at least four human-pathogenic genotypes (HEV-G1, -G2, -G3, and -G4) and several subtypes (6). HEV-G1 is hyperendemic in Asia and Africa and frequently causes large outbreaks of acute hepatitis (7). This genotype has also been detected in Cuba, Uruguay, and Venezuela (3-4). HEV-G2 has been reported in Mexico and some countries in Africa. HEV-G3 and -G4 are zoonotic viruses and have been detected in humans and animals (mainly pigs). 
HEV-G3 is detected in many countries of the world and is the genotype most frequently found in South America. HEV-G4 is almost exclusively restricted to Asia $(3,4,7)$. HEV genotypes and reservoirs from nine LAC countries (Argentina, Bolivia, Brazil, Colombia, Costa Rica, Cuba, Mexico, Uruguay, Venezuela) (8-19) are shown in Table 1. Specific clinical manifestations of HEV infection have been tentatively associated with distinct genotypes; for example, HEV-G1 is related to fulminant acute hepatitis in pregnancy, whereas HEV-G3 is associated with chronic liver disease in immunosuppressed patients $(2,7)$.

The symposium "Epidemiology of HEV infection and associated Immune Response" was held at the Universidad de Guadalajara, Mexico, on 14 June 2017, to define the status of research on HEV infection in Cuba, Mexico, and Uruguay compared to the situation in Germany. The scientists attending the meeting 1) identified specific research gaps in understanding HEV transmission and the resulting impact on development of the disease in these three countries, and 2) proposed specific recommendations for implementing standardized serologic and molecular diagnostic methods and epidemiologic, basic, and applied research aimed to develop prevention and handling strategies for this infection. Associated comorbidities in the three LAC countries were also discussed.

\section{CURRENT STATUS OF HEV RESEARCH AND MANAGEMENT IN GERMANY VERSUS THREE LAC COUNTRIES: CUBA, MEXICO, AND URUGUAY}

\section{HEV in Germany: an example of the current situation in Europe}

During the last decade, interest in HEV infections has been largely increasing in Europe, mainly driven by the identification of animal reservoirs for $\mathrm{HEV}$ in

TABLE 1. Reported HEV genotypes and host/source of infection in LAC

\begin{tabular}{|c|c|c|c|}
\hline Country & HEV host/source & HEV genotype & Source \\
\hline \multirow[t]{3}{*}{$\overline{\text { Argentina }}$} & Environment & 3 & (3) \\
\hline & Human & 3 & (4) \\
\hline & Swine & 3 & (4) \\
\hline \multirow[t]{2}{*}{ Bolivia } & Human & 3 & (4) \\
\hline & Swine & 3 & (4) \\
\hline \multirow[t]{2}{*}{ Brazil } & Human & 3 & (4) \\
\hline & Swine & 3 & $(4,8)$ \\
\hline \multirow[t]{3}{*}{ Colombia } & Environment & 3 & (9) \\
\hline & Human & 3 & (10) \\
\hline & Swine & 3 & $(11,12)$ \\
\hline Costa Rica & Swine & 3 & (3) \\
\hline \multirow[t]{3}{*}{ Cuba } & Dolphin & $3^{a}$ & (13) \\
\hline & Human & 1 and 3 & (14) \\
\hline & Swine & 3 & (15) \\
\hline \multirow[t]{2}{*}{ Mexico } & Human & 2 & (16) \\
\hline & Swine & 3 & (3) \\
\hline Uruguay & Human & 1 and 3 & $(17,18)$ \\
\hline Venezuela & Human & 1 and 3 & (19) \\
\hline
\end{tabular}

Source: Compiled by the authors based on published data.

a Provisionally classified as genotype 3 .
European countries (20). A comparison of the number of HEV-related scientific reports published in Europe versus LAC countries illustrates the overall increase in research activity as well as the differences between the two regions (Figure 1). In Germany, hepatitis E has been a notifiable disease since 2001. An increase in hepatitis E cases has been identified in recent years, with 51 cases in 2006 and 1993 cases in 2016. Improved awareness and diagnosis are suspected as reasons for the increase. Detailed molecular investigations on HEV transmission identified 1) pigs and wild boars as the main HEV reservoirs in Germany and 2) several common HEV-G3 subtypes circulating in animals and humans (21). HEV-RNA was also detected in meat products. Currently, cell culture systems are being developed and used for the determination of HEV stability. These cell culture systems will 1) enable risk assessments of distinct food products as sources of infection and 2) identify reliable inactivation methods (22). Other activities focus on further harmonization of HEV detection methods in humans, animals, and food as well as therapeutic methods for treating acute and chronic disease. Screening of blood banks for HEV for prevention of transfusion-transmitted infections is also being discussed. Information for hygienic and safe preparation of food and specific suggestions for risk groups have been made available for the public.

\section{HEV in Cuba: epidemiology and molecular characterization}

HEV infection is a significant cause of sporadic cases and outbreaks of acute viral hepatitis in Cuba, where the prevalence of infection ranges from $5.3 \%$ to $10 \%$ in open populations (23). Coinfection of HEV with hepatitis A virus (HAV), hepatitis B virus (HBV), and hepatitis $\mathrm{C}$ virus (HCV) has been serologically identified in Cuba, but HEV-HAV is the most common combination, reflecting the similar transmission routes of these viruses (24). High detection rates of anti-HEV antibodies (35.8\%) are described for persons who work in contact with swine. Age and time spent working on farms are risk factors associated with HEV infection in swine workers. HEV-G1a and HEV-G1d have been repeatedly identified in the Cuban human population. In addition, HEV-G3a has been detected in pigs and in subclinically infected farm workers (15). Phylogenetic analysis shows that human and swine HEV strains are closely related, with $94 \%-99 \%$ nucleotide sequence identity. Furthermore, seroconversion and HEV-G3b have been recently identified in bottlenose dolphins (Tursiops truncates) in Cuba (13), but the clinical relevance of this infection requires further investigation. Thus, zoonotic HEV-G3 and epidemic HEV-G1 strains seem to co-circulate in Cuba.

\section{Genetic variability of HEV in Mexico}

HEV-G2 was first described in an outbreak in Mexico in the late 1980s and continues to be an enigma for virology. Thirty-one years after this outbreak, no new reports 
FIGURE 1. Number of scientific reports related to HEV in Europe and LAC

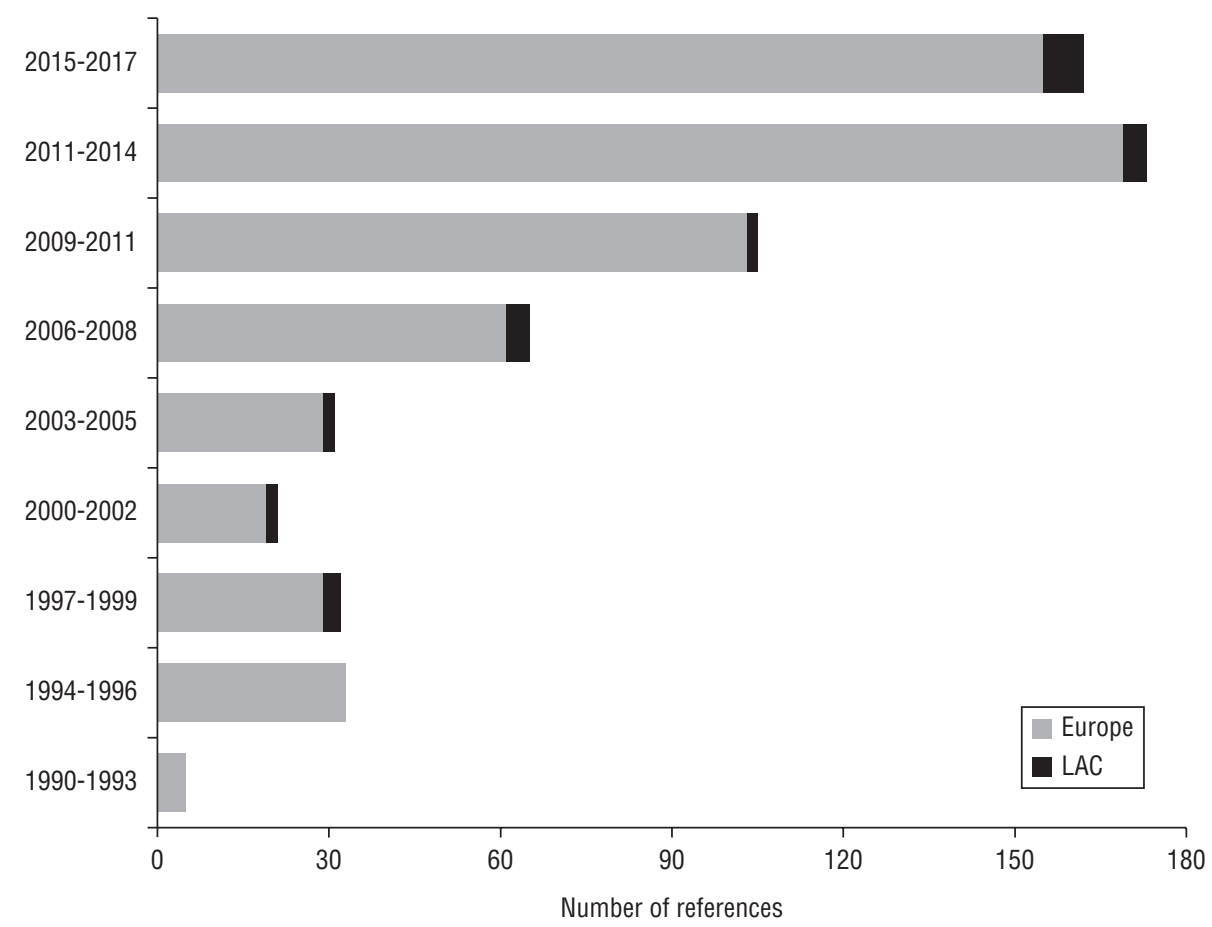

Source: References found in PubMed (https://www.ncbi.nlm.nih.gov/pubmed) on 3 July 2017, searching on "hepatitis E virus" and "Europe," "hepatitis E virus" and "Latin America," and "hepatitis E virus" and "Caribbean."

of HEV-G2 in Mexico have been published, and no other data on this genotype are available from government or public sources. More recent investigations in Mexico have identified HEV-G3 infections in animals (3). A high seroprevalence of HEV in samples from cirrhotic patients with no other etiologic agent present has been reported (25), suggesting an HEV role in the development of chronic liver illness. Seroconversion has also been found in deer (26) and farmed pigs intended for human consumption (27). Based on these findings, the expected seroprevalence and risk of HEV infection in Mexico is rather high, as reported in HAV-HEV coinfected children (28). Preliminary estimates for the general population suggesting that HEV causes unnoticed infections in Mexico support this hypothesis, indicating a potential public health concern that is not sufficiently documented.

\section{HEV in the environment, humans, and swine in Uruguay}

HEV was first associated with acute clinical hepatitis in Uruguay during 2009 and 2010. Since then, the number of cases has increased. Molecular epidemiology of HEV suggests that HEV-G3 is most prevalent among the human population, but epidemic HEV-G1 strains have also been reported $(17,18)$. Phylodynamic and evolutionary studies on HEV-G3 isolates have shown that HEV infection in Uruguay is an emergent process. All detected HEV-G3 strains belong to a European lineage and have a common ancestor dating to approximately 15 years ago (29). Seroprevalence data suggest that HEV is widely dis- tributed among swine and wild boars in Uruguay. These reservoirs constitute a potential risk for zoonotic transmission of HEV. In addition, HEV-G1 has been detected in water matrices from suburban areas with poor sanitary conditions in Uruguay. However, the exact role of this source of contamination and its impact on human health remain largely unknown.

\section{IMMUNOPATHOGENESIS OF HEV}

Given that HEV is a noncytopathic virus, the liver damage resulting from the infection is not directly associated with the virus replication. Liver damage is likely produced by the virus-specific, cell-mediated immune response to infected hepatocytes. Significant progress has been made toward understanding the immunopathogenesis of HEV in cases from European and North American countries and in those from outbreaks in Asia. In contrast, studies in LAC populations are scarce. More studies in these populations are needed because of the ethnic complexity of the LAC region, which may affect clinical outcomes and treatment strategies for $\mathrm{HEV}$ infection. Given the availability of an HEV vaccine in China, understanding the determinants for susceptibility and resistance to infection is imperative in different regions throughout the world.

\section{IDENTIFIED RESEARCH GAPS AND RECOMMENDATIONS}

HEV infection is common in LAC countries but has not been completely characterized. The following 
research gaps and recommendations were identified at the symposium in Mexico, based on reported research experiences from Cuba, Mexico, and Uruguay:

1. Research gap: The burden of diseases caused by HEV infection is not known.

Recommendation: Implementation of a notification system for HEV cases to help estimate the impact of infections on human health.

2. Research gap: Detection methods for HEV are not harmonized, and high inter-laboratory variability is expected.

Recommendation: Since 2009, an international WHO standard for HEV ribonucleic acid (RNA) has been available for use in nucleic acid amplification technique (NAT)-based assays. Validation of diagnostic tests in laboratories in the LAC region should be performed using this standard in order to harmonize methods and enable comparison of epidemiologic data.

3. Research gap: Genetic characterization of circulating HEV strains is not yet routinely established.

Recommendation: Analysis of the genetic HEV variability in the general population, high-risk populations, and animal reservoirs is necessary to identify virus transmission pathways and epidemiologic presentations.

4. Research gap: The consequences of acute HEV infection for specific risk groups have not been investigated.

Recommendation: Studies are needed to determine the risk of acute infection in children and pregnant women and the impact of the HAV-HEV coinfection in the LAC region. The effects of high pork meat consumption and deficient sanitary conditions need to be determined. Similarly, investigations on acute HEV infection as a risk factor for exacerbation of liver damage, within the context of chronic liver diseases commonly found in Cuba, Mexico, and Uruguay (e.g., fatty liver disease, obesity, chronic HBV and HCV infection, and high alcohol consumption), should be assessed.

5. Research gap: The mechanisms involved in chronic liver damage (fibrosis and cirrhosis) in HEVinfected immunosuppressed patients (e.g., organ transplant patients, patients receiving chemotherapy, and HIV patients) are not known so far. In addition, management strategies for patients with liver damage due to chronic HEV infection are not harmonized.

Recommendation: Further studies to uncover the mechanisms of liver damage in chronically HEVinfected patients are required.

6. Research gap: The role of genetic factors in HEVinfected patients, which may influence immune response, disease outcome, and response to therapy, has not been extensively studied.
Recommendation: Investigations on HEV-related immunopathogenesis and the influence of host genetic factors on HEV infection are required.

7. Research gap: The risk of blood banks as a source of HEV infection has not been analyzed.

Recommendation: Studies assessing HEV contamination rates in blood donations and blood products should be initiated.

8. Research gap: The detection of HEV in multiple animal reservoirs has been demonstrated, but the relative importance of animals as a source of human infection is not known.

Recommendation: Investigations on transmission chains from animal reservoirs to humans, including the food-borne route, should be initiated.

9. Research gap: The presence of HEV in the wastewater of cities in Uruguay has been demonstrated, although the importance of this type of environmental contamination for human hepatitis E cases remains unknown.

Recommendation: Sources of HEV contamination of the environment should be identified.

10. Research gap: The systems currently available for propagation of HEV are unsophisticated, inefficient, and often poorly reproducible.

Recommendation: A reliable cell culture system would help in the investigation of 1) HEV inactivation, 2) HEV drug discovery, and 3) immune defense strategies against HEV. Efforts to improve cell culture systems, using local HEV strains, should be made.

11. Research gap: Education of the public and health professionals on the transmission pathways of $\mathrm{HEV}$ is not implemented in Cuba, Mexico, or Uruguay. Recommendation: Information on the hygienic and safe preparation of food and drinking water and specific suggestions for risk groups should be made available to the public, and to health care professionals.

\section{CONCLUSIONS}

Given the WHO recommendations for eradicating infectious hepatitis for 2030, joint efforts are needed to assess the disease burden due to HEV in LAC countries. As a first step, the symposium described above highlighted research gaps and proposed recommendations for research on and management of HEV infection in Cuba, Mexico, and Uruguay. Given similar demographic, sanitary, and economic conditions in other LAC countries that could predispose them for HEV transmission and infection, these research gaps and recommendations might apply to the entire region. However, future studies are required to determine the distinct needs for handling HEV infections in specific LAC countries. 
Funding. The symposium "Epidemiology of HEV Infection and Associated Immune Response," held at the Universidad de Guadalajara (UDG) in Mexico, 14 June 2017, was sponsored by Mexico's National Council of Science and Technology (Consejo Nacional de Ciencia y Tecnología, CONACYT) (grant \#246839) and supported by UDG.

\section{Conflicts of interest. None.}

Disclaimer. This report is an independent declaration of the scientists attending the abovementioned symposium, compiled as a summary of meeting discussions on the status of research on HEV infection in Cuba, Mexico, and Uruguay, compared to the situation in Germany, and does not reflect policies from any federal agency or public institution.

Authors hold sole responsibility for the views expressed in the manuscript, which may not necessarily reflect the opinion or policy of the RPSP/PAJPH or the Pan American Health Organization (PAHO).

\section{REFERENCES}

1. World Health Organization. Global hepatitis report, 2017. Geneva: WHO; 2017. Available from: http:// www.who.int/hepatitis/publications/global-hepatitis-report2017 /en/

2. Lhomme S, Marion O, Abravanel F, Chapuy-Regaud S, Kamar N, Izopet J. Hepatitis E pathogenesis. Viruses. 2016;8(8):212. doi: 10.3390/ v8080212.

3. Fierro NA, Realpe M, MerazMedina T, Roman S, Panduro A. Hepatitis E virus: an ancient hidden enemy in Latin America. World J Gastroenterol. 2016;22(7):2271-83. doi: 10.3748/wjg.v22.i7.2271.

4. Echevarria JM, González JE, LewisXimenez LL, Dos Santos DR, Munné MS, Pinto MA, et al. Hepatitis E virus infection in Latin America: a review. J Med Virol. 2013;85(6):1037-45. doi: 10.1002/ jmv.23526.

5. Salines M, Andraud M, Rose N. From the epidemiology of hepatitis $\mathrm{E}$ virus (HEV) within the swine reservoir to public health risk mitigation strategies: a comprehensive review. Vet Res. 2017;48(1):31. doi: 10.1186/s13567-017-0436-3.

6. Smith DB, Simmonds P, Jameel S, Emerson SU, Harrison TJ, Meng XJ, et al. Consensus proposals for classification of the family Hepeviridae. J Gen Virol. 2014;95(Pt 10):2223-32.

7. Khuroo MS, Khuroo NS. Hepatitis E: discovery, global impact, control and cure. World J Gastroenterol. 2016;22(31):7030-45.

8. Passos-Castilho AM, Granato $\mathrm{CFH}$. High frequency of hepatitis $\mathrm{E}$ virus infection in swine from South Brazil and close similarity to human HEV isolates. Braz J Microbiol. 2017; 48(2):373-9.

9. Baez PA, Lopez MC, DuqueJaramillo A, Pelaez D, Molina F, Navas MC. First evidence of the Hepatitis E virus in environmental waters in Colombia. PLoS One. 2017;12(5):e0177525-40.
10. Rendon J, Hoyos MC, di Filippo D Cortes-Mancera F, Mantilla C, Velasquez MM, et al. Hepatitis E virus Genotype 3 in Colombia: survey in patients with clinical diagnosis of viral hepatitis. PLoS One. 2016;11(2):e0148417-29.

11. Gutiérrez-Vergara C, Quintero J, Duarte JF, Suescún JP, LópezHerrera A. Detection of hepatitis E virus genome in pig livers in Antioquia, Colombia. Genet Mol Res. 2015;14(1):2890-99.

12. Forero J, Gutiérrez-Vergara C, Parra J, Correa G, Rodríguez B, Gutiérrez L, et al. Phylogenetic analysis of Hepatitis E virus strains isolated from slaughter-age pigs in Colombia. Infect Genet Evol. 2017;49:138-45.

13. Montalvo Villalba MC, Cruz Martínez D, Ahmad I, Rodriguez Lay LA, Bello Corredor M, Guevara March C, et al. Hepatitis E virus in bottlenose dolphins Tursiops truncatus. Dis Aquat Organ. 2017;123(1): 13-8. doi: 10.3354/dao03085.

14. Villalba Mde L, Lay Lde L, Chandra V, Corredor MB, Frometa SS, Moreno AG. Hepatitis E virus genotype 1, Cuba. Emerg Infect Dis. 2008;14 (8):1320-2. doi: 10.3201/ eid1408 080049.

15. de la Caridad Montalvo Villalba $\mathrm{M}$, Owot JC, Benedito EC, Corredor MB, Flaquet PP, Frometa SS, et al. Hepatitis E virus genotype 3 in humans and swine, Cuba. Infect Genet Evol. 2013;14:335-9. doi: 10.1016/j.meegid.2012.12.022.

16. Huang CC, Nguyen D, Fernandez $J$ Yun KY, Fry KE, Bradley DW. Molecular cloning and sequencing of the Mexico isolate of hepatitis $\mathrm{E}$ virus (HEV). Virology. 1992;191 (2):550-8.

17. Mirazo S, Ramos N, Russi JC, Arbiza J. Genetic heterogeneity and subtyping of human Hepatitis $\mathrm{E}$ virus isolates from Uruguay. Virus Res. 2013;173(2):364-70. doi: 10.1016/j.virusres.2013.01.005.
18. Mirazo S, Mainardi V, Ramos N, Gerona S, Rocca A, Arbiza J. Indigenous hepatitis $\mathrm{E}$ virus genotype 1 infection, Uruguay. Emerg Infect Dis. 2014;20(1):171-3. doi: 10.3201/eid2001.131471.

19. García CG, Sánchez D, Villalba MC, Pujol FH, de Los Ángeles Rodríguez Lay L, Pinto B, et al. Molecular characterization of hepatitis $\mathrm{E}$ virus in patients with acute hepatitis in Venezuela. J Med Virol. 2012;84(7):1025-9. doi: 10.1002/ jmv.23277.

20. Aspinall EJ, Couturier E, Faber M, Said B, Ijaz S, Tavoschi L, et al. Hepatitis E virus infection in Europe: surveillance and descriptive epidemiology of confirmed cases, 2005 to 2015. Euro Surveill. 2017;22(26). pii: 30561. doi: 10.2807 / $1560-7917$. ES. 2017. 22.26.30561.

21. Oliveira-Filho EF, Bank-Wolf BR, Thiel HJ, König M. Phylogenetic analysis of hepatitis $\mathrm{E}$ virus in domestic swine and wild boar in Germany. Vet Microbiol. 2014;174(12):233-8. doi: 10.1016/j.vetmic.2014. 09.011

22. Cook N, D'Agostino M, Johne R. Potential approaches to assess the infectivity of hepatitis $\mathrm{E}$ virus in pork products: a review. Food Environ Virol. 2017;9(3):243-55. doi: 10.1007/s12560-017-9303-7.

23. Villalba MC, Guan M, Pérez A, Corredor MB, Frometa SS, Moreno $A G$, et al. Seroprevalence of antibodies to hepatitis $\mathrm{E}$ virus in two large communities in Havana, Cuba. Trans R Soc Trop Med Hyg. 2010;104(12):772-6. doi: 10.1016/j. trstmh.2010.08.006.

24. Rodríguez Lay Lde L, Quintana A, Villalba MC, Lemos G, Corredor MB, Moreno AG, et al. Dual infection with hepatitis $A$ and $E$ viruses in outbreaks and in sporadic clinical cases: Cuba 1998-2003. J Med Virol. 2008;80(5):798-802. doi: 10. 1002/jmv.21147. 
25. Panduro A, Escobedo Meléndez G, Fierro NA, Ruiz Madrigal B, Zepeda-Carrillo EA, Román S. Epidemiología de las hepatitis virales en México. Salud Publica Mex. 2011;53 Suppl 1:S37-45.

26. Medrano $\mathrm{C}$, Boadella $\mathrm{M}$, Barrios $\mathrm{H}$, Cantú A, Garcia Z, de la Fuente J, et al. Zoonotic pathogens among white-tailed deer, northern Mexico, 2004-2009. Emerg Infect Dis. 2012;18(8):1372-4. doi: 10.3201/ eid1808.111902.

27. Merino-Ramos T, Martín-Acebes MA, Casal J, Saiz JC, Loza-Rubio E.
Prevalence of hepatitis $\mathrm{E}$ virus (HEV) antibodies in Mexican pigs. Food Environ Virol. 2016;8(2):156-9. doi: $10.1007 /$ s12560-016-9231-y.

28. Realpe-Quintero M, CopadoVillagrana ED, Trujillo-Ochoa JL, Alvarez AH, Panduro A, Fierro NA. Cytokine signatures discriminate highly frequent acute hepatitis $A$ virus and hepatitis $E$ virus coinfections from monoinfections in Mexican pediatric patients. Pediatr Infect Dis J. 2017;36(7):689-92. doi: 10.1097/ INF.0000000000001556.
29. Mirazo S, Mir D, Bello G, Ramos N, Musto H, Arbiza J. New insights into the hepatitis E virus genotype 3 phylodynamics and evolutionary history. Infect Genet Evol. 2016;43:26773. doi:10.1016/j.meegid.2016.06.003.

Manuscript submitted 28 July 2017. Revised version accepted for publication on 1 November 2017

RESUMEN El 14 de junio del 2017 se realizó en la Universidad de Guadalajara (México) un simposio sobre las características epidemiológicas de la infección por el virus de la hepatitis E (VHE) y la respuesta inmunitaria asociada. El objetivo

\section{Retos en la investigación y el tratamiento de la infección por el virus de la hepatitis E en Cuba, México y Uruguay} fue definir el estado de las investigaciones sobre la infección por el VHE en tres países de América Latina y el Caribe - Cuba, México y Uruguay- en comparación con la situación en Alemania. Los científicos señalaron que para comprender la transmisión del VHE y la consiguiente repercusión en el avance de la infección en estos tres países latinoamericanos aún faltan investigaciones sobre ciertos temas específicos. También analizaron recomendaciones concretas para poner en práctica métodos estandarizados de diagnóstico serológico y molecular, y realizar investigaciones epidemiológicas, básicas y aplicadas a fin de elaborar estrategias de prevención y tratamiento de esta infección y las comorbilidades asociadas en los tres países antes mencionados. Considerando que otros países de América Latina y el Caribe presentan condiciones demográficas, sanitarias y económicas similares que podrían implicar una predisposición a un riesgo alto de transmisión del VHE y de infección por este virus, este análisis sobre las brechas y recomendaciones en el ámbito de la investigación podría aplicarse en toda la subregión. El presente informe fue elaborado por los participantes del simposio sobre la base de: 1) presentaciones del simposio; 2) revisiones bibliográficas; y 3) debates en grupos.

Palabras clave
Virus de la hepatitis E; Cuba; México; Uruguay; América Latina; región del Caribe. 
RESUMO O simpósio Epidemiologia da infecção pelo vírus da hepatite E (HEV) e resposta imune associada foi realizado na Universidade de Guadalajara, no México, em 14 de junho de 2017, para determinar a situação da pesquisa em HEV em

Desafios em pesquisa e tratamento da infecção pelo vírus da hepatite E em Cuba, México e Uruguai três países da América Latina e Caribe (ALC) - Cuba, México e Uruguai em comparação à Alemanha. Os especialistas identificaram lacunas específicas nas pesquisas no que se refere ao entendimento da transmissão do HEV e ao impacto resultante do surgimento da doença nos três países da ALC mencionados. Também foram debatidas recomendações aos três países da ALC, especificamente implementar métodos sorológicos e moleculares padronizados de diagnóstico e realizar pesquisa epidemiológica, básica e aplicada visando elaborar estratégias de prevenção e de enfrentamento da infecção e das comorbidades associadas. Diante da semelhança das condições demográficas, econômicas e de saúde que poderia predispor outros países da ALC a um maior risco de transmissão e infecção de HEV, as lacunas em pesquisa e recomendações provavelmente se aplicam à toda a Região da ALC. Este relatório foi preparado pelos participantes do encontro embasado nas apresentações do simpósio, revisão da literatura científica e discussões em grupo.

Palavras-chave Vírus da hepatite E; Cuba; México; Uruguai; América Latina; região do Caribe. 